\title{
CAN THE TAYLOR RULE BE A GOOD GUIDANCE FOR POLICY? THE CASE OF 2001-2008 REAL ESTATE BUBBLE
}

\section{Mateusz Machaj*}

\begin{abstract}
John Taylor (2009) argues that if the Federal Reserve had followed his famous monetary-policy rule, the severe recession that resulted from the real estate bubble could have been avoided. While one may agree with Taylor's empirical analysis and accept his demonstration that his proposed rule would lead to a more stable economic environment, it is unclear whether central banks are capable of avoiding bubbles by simply following the Taylor rule. One can construct various Taylor rules from the data. Some of those rules model what the Federal Reserve actually did. Following the specific type of Taylor rule recommended by John Taylor would in fact amount to a better monetary policy, but only because it calls for setting interest rates higher.

In the second section, we introduce Taylor rules. In the third section, we apply these rules to monetary policy since 2001. The fourth section situates the Taylor rule in the Wicksellian framework of interest rates and macroeconomic stability. In the fifth section, we discuss the effects of policy rules on macroeconomic stability.
\end{abstract}

Keywords: Taylor Rule, crisis of 2008, monetary policy, business cycle theory

JEL Classification: E3, E5

\section{Introduction}

John Taylor's eminent analysis (1993) of monetary-policy tools was inspired by the rules vs. discretion debate. According to the advocates of rules, central banks should adhere to clearly defined principles, such as a constant rate of growth of the money supply. The critics of this approach advocated that central banks engage in active and short-term oriented monetary policy to temper macroeconomic fluctuations. Because Taylor found the sharp distinction between discretion and rules artificial, he proposed a way to integrate both camps' contributions. His proposal allows the central bank to react when important variables change in the short term. Yet it is still a rule, since the authorities are obliged to follow clear procedures and the public can adjust their actions to a predefined public policy.

\section{The Taylor Rule and Taylor Rules}

Initially the rule described what the central bank actually did. It explained why the Federal Reserve performed better in the eighties and failed in the seventies. A normative

Mateusz Machaj, Faculty of Social and Economic Studies, Jan Evangelista Purkyne University in Usti nad Labem, Czech Republic, Institute of Economic Sciences, University of Wroclaw, Wroclaw, Poland (m.machaj@prawo.uni.wroc.pl). 
recommendation that followed naturally from this positive analysis made monetary policy successful in the eighties, and Taylor later advised this should become the rule for conducting such policy (Taylor, 1995, p. 19). The rule is based on an assumption about the desired rate of interest and makes a stable economic environment possible. That desired level of the interest rate should be set (or perhaps one may say discovered) by the central bank according to the following illustrative equation (Taylor, 1993, p. 202):

$$
R=r^{*}+p+0.5\left(p-p_{i}^{*}\right)+0.5 y
$$

$R$ is the interest rate set by the central bank, $r^{*}$ is the real interest rate, $p$ is a price index for inflation, $p_{i}$ is the target inflation, and $y$ is the output gap that results from a 1 per cent deviation of real output from potential output (i.e., output corresponding with full employment). Assuming target rate of inflation at 2, and real interest rate at 2, in a simplified form the equations is: $R=1.5 * p+0.5 * y+1$. This equation allows policy makers to follow both monetarist and Keynesian teachings: it calls for policy to aim for a desired price level and to stimulate aggregate demand to lower the gap between potential and actual output. No central bank has announced the commitment to follow, such rule (Svensson, 2003 , p. 25). Even though central banks do not officially recognize that they follow this rule, it plays a great role in the art of monetary policy in practice (Bernanke, 2007). Also even though central banks differ in their particular policies, they agree that by setting interest rates they are aiming at a particular inflation rate and potential-output level (Walsh, 2003, p. 265). In some cases the Taylor Rules may even be used to calculate the predictability of the exchange rates between two separate currencies (e.g. Molodtsova et al., 2003).

The equation appears to suggest a simple recipe for interest-rate policies. Assume that price inflation is 2 per cent and the economy is at "full employment," and thus the output gap is zero. According to the above rule, the central bank should set the equilibrium rate of interest at 4 per cent. If prices rise by 1 per cent more, the central bank should lean against the wind by increasing the interest rate disproportionately by 1.5 per cent. Suppose, on the other hand, unemployment rises and the output gap falls to -1 per cent. Assuming a 2 per cent target inflation rate, the central bank should lower the interest rate to 3.5 per cent. Therefore the parameters of price inflation and the output gap in this particular equation ( 1.5 per cent and 0.5 per cent) give more credit to monetarist teachings than to classic Keynesian ones. They suggest one should be more concerned about the price level than about the output gap, although the equation itself still incorporates Keynesian views. ${ }^{1}$

These were the parameters that John Taylor used in his original article, where he described the monetary policy of the eighties while also demonstrating that during this period monetary policy was better than in the seventies. From the description alone, macroeconomists inferred that following this rule is perhaps a suitable recipe for macroeconomic stability. The devil, however, is in the details. Those details indicate that there is not just one, universally recognized Taylor rule, but many. One may use different parameters for price inflation and the output gap, depending on how one interprets the data. ${ }^{2}$ Athanasios Orphanides pointed out in many articles (e.g. Orphanides, 2001, pp. $964 \mathrm{ff}$ ) that a central bank can use very different types of data: (1) real-time data; (2) revised data; or even (3) projected data.

1 Of course price inflation and the output gap are expressed in entirely different units, even though arithmetically they sum up to one recommendation.

2 There are no such stable coefficients in the case of economic variables, especially ones related to aggregates, since those may merely reflect changes rather than constants. 
After collecting real-time data, central banks can correct and adjust it to produce revised data. The central bank cannot act on revised data, since this data does not exist at its moment of choice and one cannot foresee precisely which information gaps are to be resolved in the future. Interestingly, when John Taylor described purportedly successful monetary policy in the 1980s, he used revised data. Real-time data for that period could have implied significantly different recommendations (Orphanides, 1999, pp. 49-57) ${ }^{3}$. But when describing the monetary policy of the beginning of the twenty-first century as misdirected (because it did not follow the Taylor rule's recommendations), Taylor (2009) used real-time data. ${ }^{4}$

Additional problems and complications arise when one bases monetary policy on a Taylor rule using probabilities of future, unknown events. The rationale for using projected data seems self-evident: a central bank is interested in future price levels and future output levels, not current ones. ${ }^{5}$ Analysts usually assume the decisions of the central bank influence the price level after around 18 months (e.g. Batini and Nelson, 2002, p. 2). Therefore models often include a lag in monetary policy. Forward-looking approach suggests policies could be focused on projected data over the longer term. So could be the Taylor Rule interested in future variables (Giannoni and Woodford, 2003, pp. 1426, 1432). According to a more responsive approach, unpredictable and short-duration cases such as crises or external supply shocks require sudden shifts in policies. But a recent rise in prices may disappear after a few quarters without any need for policy changes. On the other hand, a change in the data could signal an accelerating rate of inflation. Perhaps prices will rise faster in the next quarter and the central bank should hike the interest rate disproportionately higher (or lower). Challenges come with others, such as how to smooth interest rates and "inertial plans" (Woodford, 1999, p. 4). Not all authors agree that interest rate smoothing should be included in monetary policy responses (Altig, 2003, p. 1040).

Due to the question of "smoothening" proposed Taylor Rules may have a form of "backward looking" or "forward looking" (Ang et al., 2007, pp. 8-14). More backward looking versions are including past decisions in the recommended paths, so that we have some version of the "path dependence". In case of more inertial approach any increases or decreases of the recommended interest rates will be sticky, or sluggish for the reason that a recommended rate will be a weighted average of the past rate and the rate from the equation (Calstrom and Fuerst, 2007, p. 194). Decisions about the future levels also collide with discussion about public reactions to monetary policy and formation of expectations. Whether we chose rational expectations for the model, or imperfect knowledge assumptions, the model's policy recommendations for the "optimal" interest rate will also differ (Orphanides and Williams, 2007, pp. 1-2).

Aside from the when problems (past data versus corrected data or predicted data) are the what problems associated with the complexity of economic variables: how does

3 "Further, while the rule may appear to describe actual policy fairly accurately when the ex post revised data are employed, it does not provide nearly as accurate a picture if real-time data are used to construct what the rule would have recommended when policy was actually set." (Orphanides, 1997, p. 21).

4 Yet revisions can take place for a long time: "For example, the annual revision in 2009 will revise data from 2006 forward" (Basu and Fernald, 2009, p. 204).

5 All methods of estimation in the trend of GDP suffer from the difficulty especially in the ending of sample data (most recent one). One of the reasons is data revisions and structural changes (Arnold, 2009, p. 289). As another analyst admits, "much still remains unknown about potential output, even along a steady-state growth path," and about its sources (Basu and Fernald, 2009, p. 197). 
one decide which types of data one should use? Two of the main variables in Taylor rules cannot be definitively measured. First, one can measure the inflation rate, with any index, in different ways. The index can be based on consumption goods (as with the CPI, e.g.) or on production goods (as in the case of deflator). Or it can account for how consumers respond to price changes (as in the case of PCE). To smooth the index, one can exclude some of the more volatile prices (like with core inflation: CPI less food and energy prices). It is thus a matter of debate how to measure and aggregate prices. The various indices differ in their measurements (Smith, 2005, pp. 1019-1020). Due to those disproportionalities, the several indices provide policy recommendations that are miles apart. A 2 per cent difference between one index and another would lead to an enormous, 3 per cent change in recommended interest rates. ${ }^{6}$

The problems associated with the second parameter, the output gap, are more challenging. Prices at least can be measured objectively; hence the index can be related to statistics. In the case of the output gap, the difference between actual output and potential output must be estimated. Even assuming away the problems of measuring actual output (e.g. whether GDP is a proper indicator of economic activity) ${ }^{7}$, it is impossible to measure potential output. Theoretically, an economy reaches potential output when all factors of production are in use. ${ }^{8}$ Potential output is achieved when plans of individuals are consistent - under those circumstances all unemployment is natural. Yet theoretical investigations are not good substitutes for empirically relevant statistics. It is questionable whether policy makers can accurately discover the potential level of output. As Ehrmann and Smets (2003, p. 1611) put it, "there are no direct measures of the aggregate supply side of the economy or the extent to which the resources in an economy are fully used". There are problems also with input measurement. ${ }^{9}$ Correct estimation of "potential output" depends on two assumptions: (1) that it is possible to arrive at one, aggregated variable, and (2) that one can properly measure various combinations of inputs compatible with potential output.

Despite these challenges, macroeconomists try several ways to estimate the level of potential output, for example, analyses of labour markets (the subject of Okun's law), Cobb-Douglas production functions, trend estimations of GDP with stochastic filtering techniques, or econometric models imitating economy's conduct (Gibbs, 1995, pp. 76-89; Brouwer, 1998, pp. 4-21). As in the case of price indices these methods lead to significantly different estimates of potential output and therefore differences in output-gap measurements and policy prescriptions.

$6 \quad$ One of the referees commenting on an earlier version of the paper pointed out that in changing variables in the Taylor rules one has merely to reparameterize the variables (e.g. from 1.5 and 0.5 to something else). This is certainly true, but it does not reach the essence of the problem of choosing the best-suited variables for an optimal monetary policy. We can treat the variable and its parameter as one thing that the policy maker has to choose among given bundles (like in the choice between $a \mathrm{CPI}$ versus $b \mathrm{PCE}$, where $a$ and $b$ are different parameters for different inflation measurements). Still it remains unclear which bundle should be chosen for the right policy.

7 Gross Domestic Product excludes a major part of productive expenditures. See Reisman, 2004, pp. 616-19.

8 i.e. full employment; the Non-Accelerating Inflation Rate of Unemployment (Meyer et al., 2001, p. 226), or Okun's “maximum production without inflationary pressure" (Basu and Fernald, 2009, p. 188).

9 As Arnold (2009, p. 277) states: "even if accurate estimates of individual stocks were available, aggregating them into a single index would be difficult because capital is heterogeneous, differing with respect to characteristics such as durability and productivity". 
Lack of constant parameters and vagueness of variables imply that there is no single Taylor rule. There are numerous Taylor rules (Drew and Hunt, 2006, p. 148) because different parameters combined with different empirical estimations suggest dissimilar policy prescriptions (even for the period originally analysed by Taylor [Orphanides, 2001, p. 973]). There are substantial disagreements "output gaps and inflation rates should be past, present, or (expected) future values, whether past values of the funds rate need to be included, and what are the appropriate magnitudes of the responses to each of these measure" (Altig, 2003, p. 1039). As a result, one cannot state that a particular monetary policy did not conform to the Taylor rule. Rather, one should state that a monetary policy did not conform to some particular Taylor rule, though it might conform to some other Taylor rule.

\section{Taylor's Taylor Rule for Monetary Policy after 2001 and Other Taylor Rules}

John Taylor argues that expansionary monetary policy in the first years of twenty-first century leads to a large expansion of credit and triggered real estate malinvestments based on subprime borrowing (Taylor, 2009, pp. 43-45). At the same time he suggests that this failure could have been avoided by conforming to the Taylor rule as the figure shows:

\section{Figure 1 | Actual Federal Funds Rate and the One Recommended by Taylor}

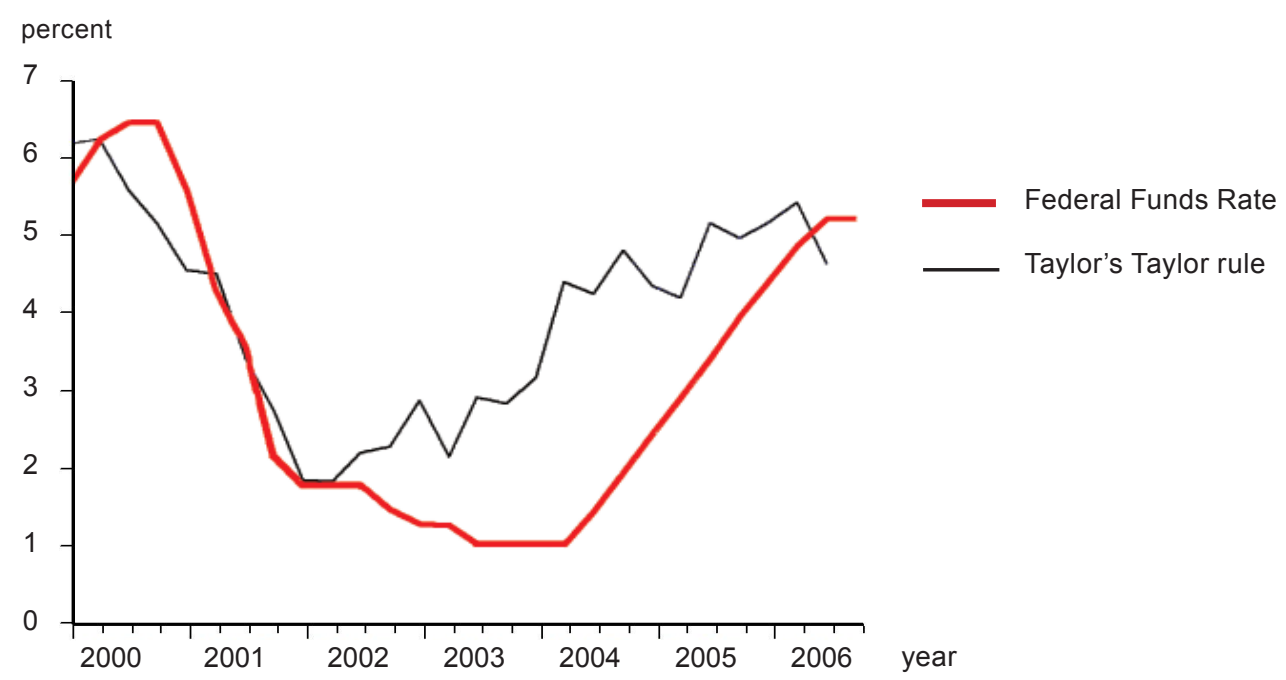

Source: Taylor 2009

Notably, Taylor's Taylor rule calls for interest-rate hikes in 2002, whereas the Federal Reserve kept the interest rates at very low level. This even leads to negative real interest rates at the height of the real-estate boom. This particular Taylor rule would lead to higher interest rates. Nevertheless, there are other Taylor rules, which could call for different policies.

As Calstrom and Fuerst (2007, p. 194) illustrate it is sufficient to modify slightly Taylor's Taylor Rule to include the smoothening aspect, and one can arrive at almost perfect conformity between the Rule and actual rates for dates from 2003. The figure demonstrates it well: 


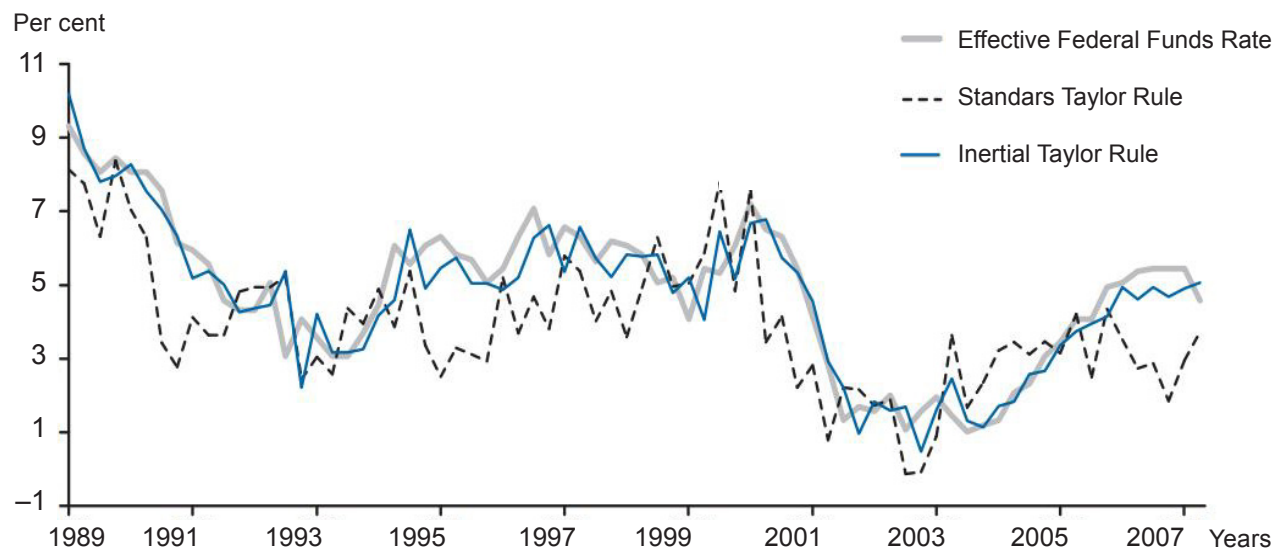

Source: Carlstrom and Fuerst 2007

David Altig (2005) also created a version of the Taylor rule that conformed to the monetary policy that the Fed actually pursued, but with different alterations. The difference between Altig's Taylor rule and Taylor's Taylor rule results from differences in data (Altig did not use real-time data). Orthodox Keynesianism would be even more radical in interest rate recommendations: let us assume Okun's classic law (1960), which states that a 1 per cent deviation of actual unemployment above the natural rate of unemployment, decreases actual output from potential output by 2-3 per cent (in order to measure output gap). To smoothen the price index, let us use CPI less food and energy. Under those assumptions, a Taylor rule would look as follows:

Figure 3 | Actual Federal Funds Rate and the One Based on Core CPI and Okun's Law Per cent

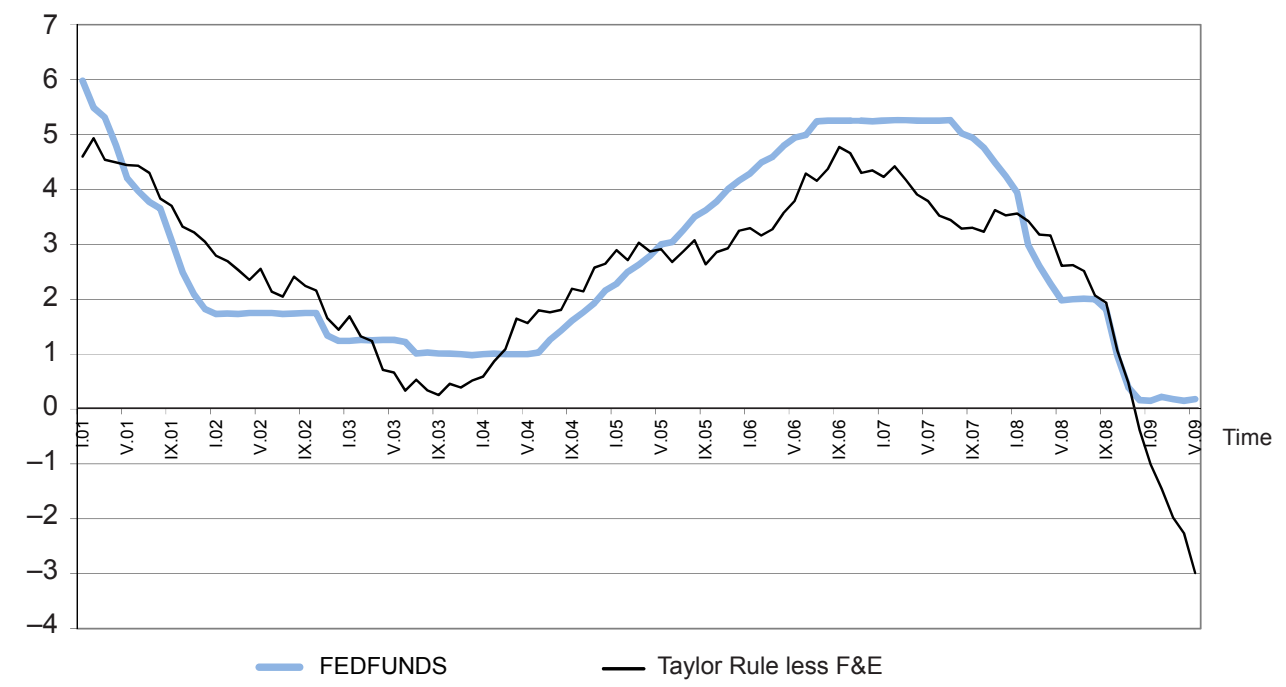

Source: author's own calculations 
As we see, one can generate various Taylor rules to advocate various monetary policies. ${ }^{10}$ The federal funds rate conformed to Altig's was too low compared to Taylor's, and was too high compared to ours. To choose a proper rule to guide monetary policy, one has to provide a standard for selecting the most appropriate version. Yet John Taylor did not give us empirical or theoretical reasons why we should favour his particular version.

\section{Wicksellian Mistake Extended}

The main theme of the Taylor rule seems to be inspired by Knut Wicksell's contributions to macroeconomics. Wicksell emphasized the essential role of the natural rate of interest in balancing the supply and demand for capital goods. In general the natural rate of interest "depends on the efficiency of production, on the available amount of and liquid capital, on the supply of labour and land, in short on all the thousand and one things which determine the current economic position of a community" (Wicksell, 1936, p. 106). This statement correctly indicates the interest rate's microeconomic functions. A few pages later, however, Wicksell incorrectly concludes that the natural rate of interest coincides with a stable price level (ibid., p. 120). Regardless, he does not give convincing arguments to show how equilibrated labour and capital markets are to coincide with a zero rate of inflation. He gives no good reason to assume that both these markets reach equilibrium. In fact, as Friedrich von Hayek demonstrated, a natural rate of interest in a growing economy may well be associated with a falling price level. Increased savings, which are used to finance investment projects, lead to increased production of goods and services. Increased supply would lead to a lower price level without a concurrent monetary expansion. ${ }^{11}$ Therefore when the interest rate reaches its natural level - when investment matches savings - prices might well decline (Selgin, 1997, p. 64). Only in a stationary society, in "which there were no additions to the supply of savings," would the natural rate of interest coincide with stable prices (Hayek, 1931, p. 218). If the central bank is interested in price-index stability, it has to conduct monetary expansion, but then the interest rate cannot any longer be at its natural level (ibid.) - it has to go down. Clearly, "efficiency of production," "available capital," "supply of factors," and a "thousand and one things" can lead to price deflation. Wicksell gave no carefully articulated reasons why the natural interest rate should generate a stable price level.

Step by step, Hayek demonstrated that the goals of stable prices and the natural rate of interest will often be in conflict. Contrary to Wicksell, the natural rate of interest will

10 Consider the following example: "A monetary authority that must conduct interest rate policy based on a Taylor rule that includes an output gap measure could make the opposite decision depending on the method used to measure drift between actual and potential output. For instance, after a positive productivity shock, the central bank could decide to instantaneously increase the nominal interest rate if based on the PFA [production function approach] gap estimates, whereas the decision would be to decrease the interest rate (...) at least in DSGE [dynamic stochastic general equilibrium model] framework" (Cahn and Sanint-Guilhem, 2009, p. 237).

11 Deflation may occur even with monetary expansion, when the pace of expansion is slower than the pace of productivity growth. Following Bernanke (2002) it seems better to call that case "declining prices", since it is different from a widespread economic crisis, when prices also decline but for opposite reasons. Bernanke argues that "deflation is in almost all cases a side effect of a collapse of aggregate demand - a drop in spending". However we define or interpret aggregate demand, an increase in production is not a fall in demand. 
at most times cause declining prices because of increases in productivity. A policy of stable prices (or prices increasing at 2 per cent rate, as central banks usually target) requires additional credit expansion and interest rates lower than the "natural" ones that would have existed under conditions of increased production.

Assume that under equilibrium conditions accumulated savings (in various forms) result in the accumulation of capital. The funds are being redirected in the production structure so that demand for capital changes: reshaping production functions leads to significant increases in productive capacity. There needs to be no reason to assume that any Wicksellian gap between "demand and supply of capital" has to be developed. At the same time due to increases in productivity a significant price deflation in the consumer market would happen (which is seen in the extreme cases in technological sectors nowadays). A very good example in which Wicksellian balance in the capital market may be accompanied by overall price deflation. A balance indicated by Hayek which may result under conditions of Wicksellian imbalance in overall level of prices.

In fact if one wants to keep the consumer price level stable under capital accumulation, a monetary expansion may be necessary at most times. Monetary expansion plays a role in boosting consumer prices so they reach a desired predetermined inflation target. Yet at the same time of boosting those prices it is also boosting credit expansion, financing the investments in capital goods to higher extent than it would result from market-determined savings rate. Wicksellian balance in consumer prices is accompanied then, by Wicksellian imbalance in capital goods market, where demand is additionally stimulated by arranged monetary policy. The price of keeping consumer prices stable may happen at a price of a capital market bubble. ${ }^{12}$

It is also possible to imagine Minsky's credit cycle, which under the conditions of fractional reserve banking leads to creation of insolvent debtors (e.g. Minsky, 1978). Under the expansionary monetary policy the conditions of high leverage open possibilities for various types of speculative (and Ponzi) borrowers. The end result is an unstable boom, which could be broken by the famous "Minsky moment". Nothing of such necessarily visualizes itself in the worrying levels of consumer prices. The monetary policy of the central bank can reach the "right" levels of the price index. Nevertheless, at the same time it may create unstable credit expansion causing macroeconomic instability (as Minsky and Hayek demonstrated).

Henceforth, similarly the supposedly "natural" rate of interest in the Taylor rule equation - with steadily increasing consumer price index - may not be consistent with macroeconomic stability if that rate is to equilibrate capital markets at most times. Taylor's approach associates the desired rate at certain level of consumer-goods prices without giving compelling reasons to do so. Just like Wicksell in his second extended interpretation. As Svensson (2003, p. 20) correctly put it, if there are other relevant and crucial variables than output gap and inflation rate, the Taylor Rule cannot be considered as optimal. Such significant variables could be more qualitative, related to the banking sector, the stock market, asset markets, levels and sustainability of debt. The examples of factors which play a certain role in describing macroeconomic stability.

12 Those interested in the described Hayekian interpretation of the 2008 recession should consult Salerno (2012). 
One way to answer the objection could be that in the Taylor Rule a variable apart from price levels may have to do with macroeconomic stability broadly understood. The output gap links macroeconomic stability in capital markets with possible scenarios of unsustainable growth. Yet the answer cannot be completely satisfying, since the variable can only reflect overall levels of particular economic features (such as overall employment, but not employment in particular industries). It treats all markets and therefore it cannot depict tensions between various markets (such as where some investment project cannot be completed). It conceals exchange (Conway and Hunt, 1997, pp. 3-4) and coordination among various stages of production. ${ }^{13}$ In the everyday practice of macroeconomic modelling, potential output is derived either from actual output or from groups of inputs (labour, capital, technology). All of the various estimation methods have a common denominator: they are based on aggregates, such as the sum of the growth of factor inputs, or depend on the concept of the representative household and the representative firm (Cahn and Saint-Guilhem, 2009, pp. 221, 223). They describe the world in averages, not the world of changes within the averages. To estimate these macroeconomic variables, model builders analyse the overall labour market, global Cobb-Douglas functions, econometric models for the economy, or Gross Domestic Product. ${ }^{14}$ While transactions may be crucial for sustainable growth and stability, the output gap can only lump them all together into one variable.

An appropriate description of the output gap is one of the biggest challenges in modern macroeconomics. Woodford argues (2001, p. 233) that the output gap must be correctly understood, if policy makers are to design proper policies. Yet even considering only one type of output gap measurement, the range of rule recommendations is significant when, as with inflation, one faces a choice of using real-time or projected or revised data (Orphanides, 2001, p. 975). Measurement errors can be so large that the optimal parameter for the output gap may even be 0 , not 0.5 (Smets, 1998, p. 16). In fact, revisions of chosen data (even if they are correct) are so substantial as to make the whole case for potential-output measurement unreliable. This is not the main difficulty, since "the bulk of the problem is due to the pervasive unreliability of end-of-sample estimates of the output trend ... [E] ven if the reliability of the underlying real-time data were to improve, real-time estimates of the output gap would remain unreliable" (Orphanides and Norden, 2002, p. 582). ${ }^{15}$

13 One can argue that it is designed to neglect those issues. Certainly so, but that means that it is designed to neglect problems of intertemporal coordination (understood as a production structure without major macroeconomic malinvestments, not as it is sometimes understood as coordination between moments of consumption).

14 A production-function approach (Claus et al., 2000, p. 11) homogenizes heterogeneous problems, because it is questionable whether capital at various stages of production can be summed up, or that it can be included in the technology variable. Capital measures are based on aggregative monetary considerations. (Due to lack of a capital variable independent from prices, the variable is not purely real, but monetary, which in a way defeats the purpose of measuring potential output as technological and objective). Trend analyses of actual GDP with various filters (such as Hodrick and Prescott's famous analysis) used in macro modelling reveal very little information about economic conditions, but more about indexes' general movements (ibid., p. 12). Similar (although less challenging) problems develop in modelling labour markets. For example "labour supply elasticity in models depends crucially on the assumption that workers are homogeneous" (Basu and Fernald, 2009, p. 200).

15 Along similar lines Chagny and Döpke (2001, p. 326) notice that "the difference between competing approaches is as large as 3 percentage points or more". 
All the methods abstract from microeconomic features and qualitative aspects of resource allocation. They can indicate growth of aggregates such as employment, production, and investment, but they cannot indicate and measure their sustainability. Macroeconomic stability is not a question of absolute spending and total employment. It is a question of economically consistent and efficient ways of spending in the "right" places and employing factors in the "right" sectors in order to avoid (unprofitable) capital consumption. An overall measure in the output gap of spending streams and fluctuations does not settle whether those streams are economically effectual and maintainable. For this reason any outputgap estimation method fails to convey information about macroeconomic stability. Laxton and Tetlow (1992, p. 5) discuss the short-lived attempt in the profession to disaggregate potential output (and observe various industries), but conclude that it was impractical, and the profession abandoned it for the input analysis in the Solow type of approach (hence aggregative). ${ }^{16}$

In other words, all measures are inspired by the Keynesian spirit expressed in Keynes's (1936, p. 379) concern about "the volume, not the direction, of actual employment." Whichever type of output gap we estimate, we deal with volume only. The gap indicates merely the amount of employment (according to the long-term trend or an aggregate production function); it does not show the direction of employment. Just as with Keynes's approach over eighty years ago, focus on the output-gap variable ignores challenges about possible malinvestments and entrepreneurial errors. Therefore the output-gap variable in the Taylor rule cannot take into account microeconomic problems, which may be caused by a mistaken monetary policy.

\section{Interest-Rate Manipulations and Macroeconomic Stability}

It is difficult to challenge the idea that interest rates set by the Federal Reserve in 2001 were too low and that they contributed significantly to the real estate boom. From a macroeconomic, as opposed to a microeconomic, perspective, the American central bank did not hit the right target interest rate level. There are two fundamental questions: (1) Can the central bank hit the right target? (2) Were low interest rates a sufficient cause for the macroeconomic turbulence of 2007-2008?

The answer to the first question reveals the core of macroeconomic reasoning and the modern understanding of interest rates. The classical, or microeconomic, approach views the interest rate as a price. It represents a trade-off between goods that can be allocated by agents over a certain time horizon. All microeconomic theories portray interest as serving microeconomic functions. Interest allows producers to allocate resources into investments of differing maturities and agents to consume now or later. In a similar manner one can interpret the production-possibilities frontier as depicting choices to employ goods to current or future production (e.g. Pindyck and Rubinfeld, 1997, pp. 548-550).

Macroeconomic models are not focussed on these considerations, although they do rely on some microfoundations and include forms of intertemporal optimization

16 Laxton and Tetlow observe (1992, p. 6) that "the profession's inability to explain potential output at the macroeconomic level has spawned some impressive efforts at disaggregation, but these have run into difficulties with data availability and have tended to be too unwieldy for use in macroeconomic models". 
(Blanchard, 1997, p. 289; McGrattan, 1997, p. 283). ${ }^{17}$ The central bank sets interest rates in accordance with its assumptions about the rates' macroeconomic influence. Despite the implicit Fisherian (consumption) trade-off, the macro models do not show interest rates as prices, that dictate the sensibility of investment projects over an extensive time horizon. Low interest rates stimulate credit expansion, expansion of industries follows, households borrow more, GDP and employment grow, though inflation may also follow. These models show stocks, flows, and reactions of all sectors as uniform and consumption and investments as moving in the same direction. The art of monetary policy does not consider the influence of interest rates on the intertemporal coordination of production, which was the subject of many of Hayek's works. ${ }^{18}$

Microfoundations were always present almost since the beginning of macroeconomics. We could find them at heart of Samuelson's neoclassical synthesis. Among other aspects microfoundations' role was highlighted by the New Neoclassical Synthesis, which includes already mentioned intertemporal optimization (Goodfriend and King, 1997, p. 255). The optimization is about the utility function presenting trade-offs between consumption and hours worked. The intertemporal disturbance may also include to some extent final goods producers and intermediate good producers (see for example Primiceri, 2006 et al., pp. 10-11). What is, however, specific in such framework is that sources for "shocks" are found in some changes due to production functions conditions, or other factors leading to discrepancy between "marginal rates of transformation" and "marginal rates of substitution". Whereas in reality the changes in the central bank's interest rates may lead to discoordination at various stages of intermediate products.

In macroeconomic models monetary policy is presented as changing undermining variables through the monetary transmission mechanism, which is working slightly differently through numerous channels in competing models (e.g. Goodfriend and King, 1997 , pp. 233, 238, 259). Changes in the money market lead to adjustments in economic activity and consequently in the real sector, since they affects costs, prices, markups. Both aggregate supply and aggregate demand are altered. During the process of targeting the inflation rate various effects may appear on the way to the final goal. In the understanding of the monetary transmission mechanism there remains a lot to be added about possible financial bubbles, financial asset pricing, credit cycles and mistaken investments. Herein lies a potential line of research in the allocation aspects of monetary forces. Such line of investigations was suggested on the edge of the crisis by Fredric Mishkin in his analysis of the real estate bubble, although he was mostly focused on reacting to bursting of the bubbles rather than not causing them in the first place (Mishkin, 2007, pp. 38-42). In fact he remained sceptical about paying any attention at all to boosted asset prices.

Macroeconomic policy modelling, such as with the Taylor rule, does not explain how the manipulation of a certain market price, the interest rate, should lead to market stability

17 In fact after many years of development of macroeconomic theory, the interest rate is not being fully analysed as arising from "microfoundations", since in macroeconomics courses it is always treated as a variable somehow related to total output (shaping it through the monetary transmission mechanism). See for example: Laubach and Williams, 2003, p. 1063. This also illustrates that despite many declarations microfoundations of modern macroeconomics were never completed.

18 Despite the fact that so-called liquidity preference and marginal product of capital may appear in various macro models, they do not constitute the basis for macroeconomic equilibrium in the Hayekian sense - for the reason that these models underemphasize heterogeneity of capital structure. 
rather than malinvestment, or risky borrowing in Minsky's sense. The range of topics on macroeconomic disequilibrium under study is restricted to such queries as the distinctive features of cost-push shocks and potential output shocks (Ehrmann and Smets, 2003, p. 1616). Even if the central bank has the will to accurately target an interest rate consistent with objective market factors, it does not have tools to do so, because it can only operate on averages and quantitative factors, which are constantly changing and constantly adjusted.

One cannot separate our second question from our first one. Were low interest rates sufficient to cause massive cluster of errors? Do low prices lead to economic problems anywhere? Possibly for the people who sell their possessions for a price significantly lower than the market price. But this change of wealth need not cause a huge constellation of mistakes. The same is the case with credit. Very often people set their interest rates below average market levels, especially when they lend to their family. But borrowing at discount prices in itself do not lead to crises. In a similar manner, if a private bank extends credit to people for a low price, it offers a premium to individual customers and loses capital. Obviously something other than this kind contributed to the Great Recession. Low price or cheap price is not enough. There are other institutional aspects to be taken into account, which cause external effects to the whole financial architecture.

All macroeconomic prescriptions, such as Taylor rules, do not take institutions into account because they are based on narrowly defined links between selected macroeconomic indices. They ignore qualitative, in favour of quantitative and misleading, causalities. They depict interest rates as means to set levels of general price inflation, growth, overall credit, or employment.

We do not here try to develop a particular story of what happened in the first decade of the twenty-first century. Rather we point out that we need to consider qualitative aspects to understand quantitative ones. We do not argue that debating the level of interest rates is pointless. Certainly lower or higher interest rates set by the central bank could have had a different impact on the real economy. We do not believe, however, that interest should be isolated from institutional aspects. It is misleading to treat interest rate as a variable that the central bank must properly set. The debate only over the level underemphasizes the importance of specific financial regulations, in which commercial banks are operating.

\section{Conclusions}

John Taylor has made two important contributions to understanding monetary policy in the beginning of the twenty-first century. He convincingly demonstrates that low interest rates contributed significantly to a housing bubble and mortgage-market expansion. His second observation is that the Federal Reserve System should have followed his famous Taylor rule in order to avoid macroeconomic problems resulting from the bubble. We approved the first thesis, but argued against the second one. To be sure, any rule recommended for interest rates higher than the actual ones would have been better than that actually followed (even a rule based on astrology). Apart from that, there may be nothing specific about the Taylor rule that makes it a panacea for macroeconomic problems. The Taylor rule is not precisely defined, has many variants, and is not rooted in an understanding of coordination in the market economy. For these reasons we cannot consider it as a universal method to conduct a successful monetary policy. The case of 2001-2008 cannot be seen as a confirmation that Taylor Rule works well as a monetary policy prescription. 


\section{References}

Altig, D. (2003). Introduction: Recent Developments in Monetary Macroeconomics. Journal of Money, Credit and Banking, 35(6b), 1039-1043, http://dx.doi.org/10.1353/mcb.2004.0015

Altig, D. (2005). What's the Fed up to? Part 2. Available at: http://macroblog.typepad.com/ macroblog/2005/06/whats_the_fed_u_1.html

Ang, A., Dong, S., Piazzesi, M. (2007). No-Arbitrage Taylor Rules. NBER Working Paper 13448, http://dx.doi.org/10.3386/w13448

Arnold, R. W. (2009). Challenges of Estimating Potential Output in Real Time. Federal Reserve Bank of St. Louis Review, 91(4), 271-290. Available at: https://research.stlouisfed.org/ publications/review/09/07/Arnold.pdf

Basu, S., Fernald, J. G. (2009). What Do We Know (and not Know) about Potential Output? Federal Reserve Bank of St. Louis Review, 94(1), 187-213. Available at: https://research. stlouisfed.org/publications/review/09/07/Basu.pdf

Batini, N., Nelson, E. (2002). The Lag from Monetary Policy Actions to Inflation: Friedman Revisited. Bank of England, External MPC Unit Discussion Paper No. 6.

Bernanke, B. S. (2002). Defl ation: Making Sure 'It' Doesn't Happen Here. Remarks by Governor before the National Economists Club, Washington, D.C.

Bernanke, B. S. (2007). Opening Remarks to the Conference on John Taylor's Contributions to Monetary Theory and Policy. Federal Reserve Bank of Dallas, Dallas, Texas.

Blanchard, O. (1997). The New Neoclassical Synthesis and the Role of Monetary Policy: Comment. NBER Macroeconomics Annual, 12, 289-293, http://dx.doi.org/10.2307/3585234

Brouwer, G. de (1998). Estimating Output Gaps. Economic Research Department, Reserve Bank of Australia Research Discussion Paper.

Cahn, C., Saint-Guilhem, A. (2009). Issues on Potential Growth Measurement and Comparison: How Structural Is the Production Function Approach? Federal Reserve Bank of St. Louis Review, 91(4), 221-240. Available at: https://research.stlouisfed.org/publications/ review/09/07/Cahn.pdf

Carlstrom, C. T., Fuerst, T. S. (2007). Inertial Taylor Rules: The Benefit of Signalling Future Policy. Federal Reserve Bank of Cleveland, Policy Discussion Paper, 193-203, http://dx.doi.org/10.2139/ssrn.1024828

Claus I., Conway, P., Scott, A. (2000). The Output Gap: Measurement, Comparisons and Assessment. Reserve Bank of New Zealand Research Paper No. 44.

Chagny, O., Döpke, J. (2001). Measures of the Output Gap in the Euro-Zone: An Empirical Assessment of Selected Methods. Vierteljahrshefte zur Wirtschaftsforschung, 70(3), 310-330, http://dx.doi.org/10.3790/vjh.70.3.310

Conway, P., Hunt, B. (1997). Estimating Potential Output: A Semi-Structural Approach. Working paper. http://dx.doi.org/10.2139/ssrn.321783

Drew, A., Hunt, B. (2000). Efficient Simple Policy Rules and the Implications of Potential Output Uncertainty. Journal of Economics and Business, 52(1-2), 143-160, http://dx.doi.org/10.1016/s0148-6195(99)00025-9

Ehrmann, M., Smets, F. (2003). Uncertain Potential Output: Implications for Monetary Policy. Journal of Economic Dynamics \& Control, 27(9), 1611-1638, http://dx.doi.org/10.1016/s0165-1889(02)00073-8

Giannoni, M. P., Woodford, M. (2003). How Forward-Looking Is Optimal Monetary Policy? Journal of Money, Credit and Banking, 35(6b), 1425-1469, http://dx.doi.org/10.1353/ mcb.2004.0029 
Gibbs, D. (1995). Potential Output: Concepts and Measurement. Labour Market Bulletin, 1995(1), 72-115. Available at: http://www.dol.govt.nz/PDFs/Imb951d.pdf

Goodfriend, M., King, R. G. (1997). The New Neoclassical Synthesis and the Role of Monetary Policy. NBER Macroeconomics Annual, 12, 231-283, http://dx.doi.org/10.2307/3585232

Hayek, F. A. (1931). Prices and Production, in Prices and Production and Other Works. F.A. Hayek on Money, the Business Cycle, and the Gold Standard. 2008. Auburn, Al: Ludwig von Mises Institute.

Keynes, J. M. (1936). The General Theory of Employment, Interest and Money. London: Macmillan.

Laubach, T., Williams, J. C. (2003). Measuring the Natural Rate of Interest. The Review of Economics and Statistics, 85(4), 1063-1070, http://dx.doi.org/10.1162/ 003465303772815934

Laxton, D., Tetlow, R. (1992). A Simple Multivariate Filter for the Measurement of Potential Output. Bank of Canada Working Paper. Available at: http://www.douglaslaxton.org/ sitebuildercontent/sitebuilderfi les/LT.pdf

McGrattan, E. (1997). The New Neoclassical Synthesis and the Role of Monetary Policy: Comment. NBER Macroeconomics Annual, 12, 283-289. DOI: 10.2307/3585233.

Meyer, L. H., Swanson, E. T., Wieland, W. V. (2001). NAIRU Uncertainty and Nonlinear Policy Rules. The American Economic Review, 91(2), 226-231, http://dx.doi.org/10.1257/aer.91.2.226

Minsky, H. (1978). The Financial Instability Hypothesis: A Restatement. Thames Papers in Political Economy, Thames Polytechnic.

Mishkin, F. S. (2007). Housing and the Monetary Transmission Mechanism. NBER Working Paper Series, http://dx.doi.org/10.3386/w13518

Molodtsova, T., Nikolsko-Rzhevskyy, A., Papell, D. H. (2011). Taylor Rules and the Euro. Journal of Money, Credit and Banking, Blackwell Publishing, 43(2-3), 535-552, http://dx.doi.org/10.1111/j.1538-4616.2011.00384.x

Okun, A. M. (1962). Potential GNP: Its Measurement and Significance. American Statistical Association, Proceedings of the Business and Economics Statistics Section.

Orphanides, A. (1997). Monetary Policy Rules Based on Real-Tim Data. Board of Governors of the Federal Reserve System Working Paper. Available at: http://www.federalreserve. gov/pubs/feds/1998/199803/199803pap.pdf

Orphanides, A. (1999). The Quest for Prosperity without Inflation. Board of Governors of the Federal Reserve System.

Orphanides, A. (2001). Monetary Policy Rules Based on Real-Time Data. The American Economic Review, 91(4), 964-985, http://dx.doi.org/10.1257/aer.91.4.964

Orphanides, A., van Norden, S. (2002). The Unreliability of Output-Gap Estimates in Real Time. The Review of Economics and Statistics, 84(4), 569-583, http://dx.doi.org/ 10.1162/003465302760556422

Orphanides, A., Williams, J. C. (2007). Inflation Targeting under Imperfect Knowledge. Economic Review, Federal Reserve Bank of San Francisco, http://dx.doi.org/10.2139/ssrn.910905

Pindyck, R. S., Rubinfeld, D. L. (1997). Microeconomics. New York: Prentice Hall Business Publishing.

Primiceri, B., Schaumburg, E., Tambalotti, A. (2006). Intertemporal Disturbances. NBER Working Paper Series, http://dx.doi.org/10.3386/w12243

Reisman, G. (2004). The Value of "Final Products" Counts Only Itself. The American Journal of Economics and Sociology, 63(3), 609-625, http://dx.doi.org/10.1111/ j.1536-7150.2004.00306.x 
Salerno, J. (2012). A Reformulation of Austrian Business Cycle Theory in Light of the Financial Crisis. The Quarterly Journal of Austrian Economics, 15(1), 3-44. Available at: https://mises. org/library/reformulation-austrian-business-cycle-theory-light-financial-crisis-0

Selgin, G. (1997). Less than Zero. London: Institute of Economic Affairs.

Smets, F. (1998). Output Gap Uncertainty: Does It Matter for the Taylor Rule? Basle, Switzerland: Bank for International Settlements, Monetary and Economic Department.

Smith, J. K. (2005). Inflation Targeting and Core Inflation. The Canadian Journal of Economics/ Revue canadienne d'Economique, 38(3), 1018-1036, http://dx.doi.org/10.1111/ j.0008-4085.2005.00314.x

Svensson, L. E. O. (2003). What Is Wrong with Taylor Rules? Using Judgment in Monetary Policy through Targeting Rules. NBER Working Paper 9421, http://dx.doi.org/10.3386/w9421

Taylor, J. B. (1993). Discretion versus Policy Rules in Practice. Carnegie-Rochester Conference Series on Public Policy, 39(1), 195-214, http://dx.doi.org/ 10.1016/0167-2231(93)90009-I

Taylor, J. B. (1995). The Monetary Transmission Mechanism: An Empirical Framework. The Journal of Economic Perspectives, 9(4), 11-26, http://dx.doi.org/10.1257/jep.9.4.11.

Taylor, J. B. (2009). Economic Policy and the Financial Crises: An Empirical Analysis of What Went Wrong. Critical Review, 21(2-3), 341-364, http://dx.doi.org/10.1080/08913810902974865

Walsh, C. E. (2003). Speed Limit Policies: The Output Gap and Optimal Monetary Policy. The American Economic Review, 93(1), 265-278, http://dx.doi.org/10.1257/ 000282803321455278

Woodford, M. (1999). Optimal Monetary Policy Inertia. NBER Working Paper 7261. DOI: 10.3386/w7261. Available at: http://www.nber.org/papers/w7261

Woodford, M. (2001). The Taylor Rule and Optimal Monetary Policy. The American Economic Review, 91(2), 232-237, http://dx.doi.org/10.1257/aer.91.2.232 